\title{
THE USE OF THERMOGRAPHY AND ITS CONTROL VARIABLES: A SYSTEMATIC REVIEW
}

O USO DA TERMOGRAFIA ESUAS VARIÁVEIS DE CONTROLE: UMA REVISÃO SISTEMÁTICA

EL USO DE LA TERMOGRAFÍA Y SUS VARIABLES DE CONTROL:UNA REVISIÓN SISTEMÁTICA

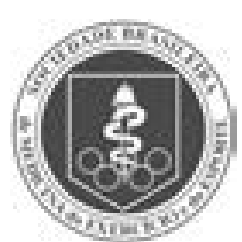

Systematic Review Article Artigo de ReVISÃo SISTEMÁtICA Artículo de Revisión Sistemática
Fernanda Viegas' (D)

(Physiotherapist)

Marco Tulio de Mello' (DD

(Physical Education Professional)

Sara Andrade Rodrigues' (ID (Physiotherapist)

Carlos Magno Amaral Costa' (iD) (Physical Education Professional) Luísa de Sousa Nogueira Freitas ${ }^{1}$ (D) (Physiotherapist)

Eduester Lopes Rodrigues² (ID) (Physiotherapist)

Andressa Silva' (ID

(Physiotherapist)

1. Universidade Federal de Minas Gerais, School of Physical Education, Physiotherapy and Occupational Therapy, Sports Department, Belo Horizonte, MG, Brazil.

2. Universidade Federal de Minas Gerais, School of Physical Education, Physiotherapy and Occupational Therapy, Physiotherapy Department, Belo Horizonte, MG, Brazil.

\section{Correspondence:}

Andressa Silva

Escola de Educação Física,

Fisioterapia e Terapia Ocupacional (EEFFTO), Universidade Federal de Minas Gerais (UFMG), Av. Antônio Carlos, 6627, Pampulha, Belo Horizonte, MG, Brazil. 31270-901. andressa@demello.net.br

\begin{abstract}
Introduction: Muscle injuries are the most frequent cause of physical disability in sports, representing a large percentage of all sports injuries. In high-performance sports in particular, there is great interest in optimizing the process of diagnosis and rehabilitation of muscle injuries in order to reduce the amount of time taken off by athletes due to their injuries. Infrared thermography, or cutaneous thermometry, is a technique used for complementary investigation of pain. It provides thermal imaging with an infrared camera, to measure the surface temperature of the body. Objective: To conduct a systematic review of the use of thermography as a functional evaluation for the identification and prevention of muscle injuries, and of the control variables used in its applicability. Methods: A systematic review was conducted in the MEDLINE, ResearchGate and Scielo databases, using the search terms:"thermography","muscle injury", "rehabilitation" and "diagnosis", searching on articles published from 2000 to 2017, in Portuguese, English and Spanish. The eligibility criteria for the studies was the use of thermography as an outcome, and the reporting of standards for evaluating skin temperature variation in athletes. Results: Following the systematic review, 94 studies were retrieved. Of these, only 12 met the criteria for inclusion in the study. Conclusion: Thermography is a suitable tool for the evaluation and prevention of muscle injuries in athletes, and care should be taken with the control variables during its use. The most efficient variables for capturing the thermographic image appear to be an environment with a temperature of between 18 and $25^{\circ} \mathrm{C}$, for 15 minutes for acclimatization, and with the individual placed in a pre-determined position, depending on the body segment being evaluated, without contact with another object. Level of evidence l; Systematic review.
\end{abstract}

Keywords: Thermography; Injury; Sport; Rehabilitation; Diagnosis.

\section{RESUMO}

Introdução: As lesões musculares são a causa mais frequente de incapacidade física nos esportes, representando uma grande porcentagem de todas as lesões esportivas. Principalmente nos esportes de alto desempenho, há um grande interesse em otimizar o processo de diagnóstico e reabilitação das lesões musculares, a fim de reduzir o período perdido pelos atletas devido às lesões. A termografia infravermelha ou termometria cutânea éuma técnica utilizada para investigação complementar da dor. Ela apresenta imagens térmicas com uma câmera infravermelho para medira temperatura da superfície do corpo. Objetivo: Realizar uma revisão sistemática sobre o uso da termografia como uma avaliação funcional para a identificação e prevenção de lesões musculares e das variáveis de controle utilizadas em sua aplicabilidade. Métodos: Foi realizada uma revisão sistemática nas bases de dados MEDLINE, ResearchGate e Scielo utilizando os seguintes termos: "thermography", "muscle injury," "rehabilitation" e "diagnosis," com busca nos artigos publicados no perío do compreendido entre 2000 e 2017, nos idiomas português, inglês e espanhol. Os critérios de elegibilidade para os estudos era a utilização da termografia como um desfecho e o registro dos parâmetros para avaliação da variação da temperatura da pele nos atletas. Resultados: Após a revisão sistemática, 94 estudos foram encontrados, sendo que desses apenas 12 atenderam aos critérios para inclusão no estudo. Conclusão: A termografia é uma ferramenta adequada para avaliação e prevenção de lesões musculares em atletas e devem-se considerar as variáveis de controle durante o seu uso. As variáveis mais eficientes para captura da imagem termográfica parece ser um ambiente com temperatura entre 18 e $25^{\circ} \mathrm{C}$, por 15 minutos para aclimatação e com o indivíduo disposto em uma posição pré-determinada, dependendo do segmento corporal a ser avaliado, sem contato com outro objeto. Nível de evidência l; Revisão sistemática.

Descritores: Termografia; Lesão; Esportes; Reabilitação; Diagnóstico.

\section{RESUMEN}

Introducción: Las lesiones musculares son la causa más frecuente de incapacidad física en los deportes, representando un gran porcentaje de todas las lesiones deportivas. Principalmente en los deportes de alto desempeño, hay un gran interés en optimizar el proceso de diagnóstico y rehabilitación de las lesiones musculares, a fin de reducir el período perdido por los atletas debido a las lesiones. La termografía infrarroja o termometría cutánea es una técnica utilizada para investigación complementaria del dolor. Presenta imágenes térmicas con una cámara de infrarrojos, para medir la temperatura de la superficie del cuerpo. Objetivo: Realizar una revisión sistemática sobre el uso de la termografía como una evaluación funcional para la identificación y prevención de lesiones musculares y de las variables de control 
utilizadas en su aplicabilidad. Métodos: Fue realizada una revisión sistemática en las bases de datos MEDLINE, ResearchGate y Scielo utilizando los siguientes términos: "thermography," "muscle injury", "rehabilitation" y "diagnosis", con búsqueda en los artículos publicados en el período comprendido entre 2000 y 2017, en los idiomas portugués, inglés y español. Los criterios de elegibilidad para los estudios era el uso de la termografía, como un resultado y el registro de los parámetros para evaluación de la variación de la temperatura de la piel en los atletas. Resultados: Después de la revisión sistemática, se encontraron 94 estudios, siendo que de esos, sólo 12 atendieron los criterios para inclusión en el estudio. Conclusión: La termografía es una herramienta adecuada para la evaluación y prevención de lesiones musculares en atletas y deben considerarse las variables de control durante su uso. Las variables más eficientes para captura de la imagen termográfica parece ser un ambiente con temperatura entre 18 y $25^{\circ} \mathrm{C}$, por 15 minutos para aclimatación y con el individuo en dispuesto en una posición predeterminada, dependiendo del segmento corporal a ser evaluado, sin contacto con otro objeto. Nivel de evidencia l; Revisión sistemática.

Descriptores: Termografí; Lesión; Deportes; Rehabilitación; Diagnóstico.

\section{INTRODUCTION}

The muscle injuries (MI) are the most frequent cause of physical disability in sports practice, representing $90 \%$ of the acute sports injuries. ${ }^{1,2}$ The Ml occur when the force exerted on the muscle leads to an excessive stretching of the myofibrils and to break next to the myotendinous junction, and may be caused by bruising or stretches. ${ }^{2}$ The risk of LM increases in professional-level athletes and their high prevalence is well documented in several sports, as in elite football, which represents 20 to $37 \%$ of injuries. ${ }^{3}$ The LM constitute almost one-third of injuries that lead to the absence of sports practice in elite football athletes, and represent more than a quarter of the time dedicated to the rehabilitation of injuries. ${ }^{4}$ In a men's elite soccer team, the MI takes a mean time of 223 days of absence, with the loss of 148 training sessions and absence in 37 official games, which justifies great relevance for the detection and treatment of MI not only for athletes, but also for the sports clubs. ${ }^{3}$ From an economic point of view, a study done in England showed that the mean cost of an elite athlete away during a month, for recovery due to injury, is approximately 50 thousand euros. ${ }^{5}$ For this reason, mainly in the sport of high yield, there is great interest in optimizing the process of identification of $\mathrm{Ml}$, to decrease the time of absence of the athlete from its role. ${ }^{6}$

Once the muscle tissue has been injured, the ruptures of cytoskeletal structures cause morphological and biochemical changes in muscle fibers, as a result of injuries on fibers, with subsequent inflammatory process. ${ }^{5}$ Yet, due to the increased blood flow near the area in which the injury occurred, there are thermal variation with increased local temperature. ${ }^{5}$ Although the diagnosis of Ml occurs usually by clinical examination, the complementary tools are important for a better understanding of the extent and location of the injury, prognosis, estimated time of recovery, appropriate time to return to sports activities and risk of recurrence. ${ }^{1,7}$ The decision on the correct moment to return to the sport is of extreme relevance, since, when carried out so early, is one of the main factors for relapse of $\mathrm{Ml}^{8,9}$ In addition, the prognosis, done in a more precise way, facilitates the planning of sports training and the composition of the team of a sports club. ${ }^{8}$

The infrared thermography (IRT) is a technique in which to obtain images with an infrared camera, which measures the surface temperature of the body. 10,11 The analysis of infrared images have as advantages: efficacy, safety, be a noninvasive technique, be painless, without contact, without ionizing radiation, without side effects and without contraindications. ${ }^{7,12,13}$ In addition to providing the temperatures of a surface in real-time images, enabling the location of the injury and be able to demonstrate physiological changes through a functional examination. ${ }^{7,12,13}$ The IRT is an important support tool for physiotherapists, aiding in the interpretation of the treatment performed with the athlete. ${ }^{14}$
The objective of this technique is not to replace the clinical examination, but rather enhance it, and serves as instant feedback..$^{13}$

To obtain good results of the images and the values of skin temperature, some experts have suggested to control and manipulate some variables, such as temperature, relative humidity, time of acclimatization and position of the subject evaluated during its use. In this context, the objective of this study was to perform a systematic review on the use of the TIR for the funcional evaluation for identification and prevention of muscle injuries, and on the control variables used in its applicability.

\section{METHODS}

Search was performed in databases MEDLINE, Research Gate e Scielo Using the following terms: "thermography", "muscle injury", "rehabilitation" and "diagnosis". The search was conducted initially with the combination of terms "thermography" and "muscle injury", and subsequently with these terms plus the term "rehabilitation" and the term "diagnosis", in distinct searches, both connected by boolean AND. In the Scielo database were used the same terms to search in portuguese:"termografia,", "lesão muscular", "reabilitação" and "diagnóstico". Were included articles published in the period between 2000 and 2017, in portuguese, english and spanish.

From the reading of the titles, abstracts and articles in their entirety, were selected articles that contain information about the parameters used for the thermography collection, having as outcomes the use of thermography, with standardized parameters for evaluation of the variation of skin temperature, variables to control the temperature, the relative humidity of the air, the time to acclimate and the position of the individual. Were excluded narrative review articles, systematic and meta-analysis.

\section{RESULTS}

After the completion of the systematic review were found 94 studies. Of these, 30 were selected after reading the titles and 12 were included after the reading in its entirety, which used the TIR with standardized parameters for evaluation of the variation of skin temperature. Table 1 describes the sample, the parameters used in the applicability of TIR, musculoskeletal injuries assessed and conclusion.

In Table 2 are presented the descriptions of control variables that the present study proposed to analyze, in addition to the number of studies that used the same parameter and the bibliographic references. In this sense, the Table 2 describes the ambient temperature, the relative humidity of the air, the time to acclimate and the position of the individual during the use of the TIR. 
Table 1. Description of the sample, the parameters used in the applicability of the thermography, musculoskeletal injuries assessed and the completion of the studies.




Table 2. Description of the control variables: ambient temperature, relative humidity, time of acclimatization, position used, number of studies that used the same parameter and the bibliographic references.

\begin{tabular}{|c|c|c|}
\hline $\begin{array}{l}\text { Ambient temperature used } \\
\text { in studies }\end{array}$ & $\begin{array}{c}\text { Number of } \\
\text { studies }\end{array}$ & Bibliographic reference \\
\hline between 18 e $25^{\circ} \mathrm{C}$ & 1 & Salazar-López et al. (2015) ${ }^{20}$ \\
\hline $20^{\circ} \mathrm{C}$ & 1 & Brioschi et al. ${ }^{12}$ (2009) \\
\hline $21,4^{\circ} \mathrm{C}$ & 1 & Oliveira et al..$^{19}$ (2016) \\
\hline Between 21,5 e $22,3^{\circ} \mathrm{C}$ & 1 & Hildebrandt et al. ${ }^{13}$ (2010) \\
\hline Between 22 e $23^{\circ} \mathrm{C}$ & 1 & Bandeira et al. ${ }^{4}$ (2014) \\
\hline Between 22 e $24^{\circ} \mathrm{C}$ & 1 & Silva et al. ${ }^{21}, 2017$ \\
\hline $23^{\circ} \mathrm{C}$ & 2 & $\begin{array}{c}\text { Bandeira et al. }{ }^{19}(2012) \\
\text { Lima et al. }{ }^{10}(2015)\end{array}$ \\
\hline Between 23 e $24^{\circ} \mathrm{C}$ & 1 & Merla et al. ${ }^{18}$ (2009) \\
\hline Between 23 e $25^{\circ} \mathrm{C}$ & 1 & Zaproudina et al. ${ }^{22}$ (2006) \\
\hline $24^{\circ} \mathrm{C}$ & 1 & $\operatorname{Ammer}^{15}(2002)$ \\
\hline $25^{\circ} \mathrm{C}$ & 1 & Chudecka et al. ${ }^{17}$ (2015) \\
\hline \multicolumn{3}{|l|}{$\begin{array}{c}\text { Relative humidity } \\
\text { used in studies }\end{array}$} \\
\hline Between 35 e $38 \%$ & 1 & Hildebrandt et al. ${ }^{13}$ (2010) \\
\hline $37 \%$ & 1 & Oliveira et al. ${ }^{19}$ (2016) \\
\hline Below 50\% & 1 & Silva et al. ${ }^{21}$ (2017) \\
\hline $50 \%$ & 3 & 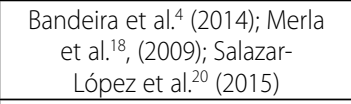 \\
\hline $55 \%$ & 1 & Brioschi et al. ${ }^{12}(2009)$ \\
\hline Below $60 \%$ & 1 & Lima et al. ${ }^{10}(2015)$ \\
\hline $60 \%$ & 1 & Chudecka et al. ${ }^{17}, 2015$ \\
\hline \multicolumn{3}{|l|}{$\begin{array}{c}\text { Time to acclimate } \\
\text { used in studies }\end{array}$} \\
\hline between 10 e $15^{\prime}$ & 1 & Salazar-López et al.. ${ }^{20}$ (2015) \\
\hline $15^{\prime}$ & 7 &  \\
\hline $20^{\prime}$ & 3 & $\begin{array}{c}\text { Chudecka et al. }{ }^{17}(2015) ; \\
\text { Hildebrandt et al. } .^{13}(2010) ; \\
\text { Merla et al. }{ }^{18}(2009)\end{array}$ \\
\hline $30^{\prime}$ & 1 & Bandeira et al. ${ }^{4}$ (2014) \\
\hline \multicolumn{3}{|l|}{ Position used in studies } \\
\hline orthostatic position & 8 & $\begin{array}{c}\text { Ammer }{ }^{15}, 2002 ; \text { Bandeira } \\
\text { et al. } .^{19}(2012) ; \\
\text { Bandeira et al. }{ }^{4}(2014) ; \text { Brioschi } \\
\text { et al }{ }^{12}(2009) ; \text { Chudecka } \\
\text { et al. } .^{17} \text { (2015); Lima et al. }{ }^{10} \\
\text { (2015); Silva et al. }{ }^{21}(2017) ; \\
\text { Zaproudina et al. }{ }^{22} \text { (2006) }\end{array}$ \\
\hline $\begin{array}{c}\text { During the implementation } \\
\text { of the program of exercises } \\
\text { on the treadmill }\end{array}$ & 1 & Merla et al. ${ }^{18}$ (2009) \\
\hline $\begin{array}{l}\text { Sitting in a chair with his } \\
\text { limbs parallel to each other }\end{array}$ & 1 & Oliveira et al. ${ }^{19}$ (2016) \\
\hline
\end{tabular}

\section{DISCUSSION}

The objective of this study was to perform a systematic review of the use of the TIR for the funcional evaluation for identification and prevention of muscle injuries and the control variables used in its applicability. The TIR has several advantages, in addition to enabling the location of the injury and be able to demonstrate physiological and metabolic changes. ${ }^{7,12,13}$ However, the lack of standardization for obtaining images seems to be a problem for the applicability of the TIR.

The ambient temperature is one of the most important factors that affect the temperature of the skin, ${ }^{11}$ and its control should be ensured during the use of the TIR, to avoid the effect of different thermoregulatory adjustments, such as the processes of loss and heat gain. ${ }^{11}$ As the ambient temperature increases, some physical processes diminishes its effectiveness to facilitate the loss of body heat. ${ }^{23}$ Table 2 presents the description of ambient temperature used in studies. It is possible to observe that the studies used the ambient temperature ranging between 18 and $25^{\circ} \mathrm{C}$, at the time of obtaining infrared images. A study of the application of the TIR in the sport suggests that the ambient temperature must be between 18 and $25^{\circ} \mathrm{C}$ during its implementation, because temperatures outside this range may affect the thermoregulatory mechanisms. ${ }^{11}$ Considering the results of our study, can realize that studies have followed this suggestion, however, it is important to emphasize that the comparison of skin temperature values obtained by TIR in environments with different temperatures, even within this range (18 and $25^{\circ} \mathrm{C}$ ), may compromise the diagnosis and monitoring of $\mathrm{Ml}$.

The conditions of the environment, as the relative humidity of the air, should receive greater attention, ${ }^{23}$ once that occurs heat exchange between the body of the evaluated and the environment. ${ }^{23,24}$ Table 2 presents the description of the relative humidity of the air used in the studies. Of the 12 articles selected for review, three did not describe the relative humidity of the air used. In addition, nine that relate this variable, it was observed that there is no consensus about the appropriate value to be used, being reported values of $38 \%$ to $60 \%$. The efficacy of heat loss decreases dramatically in humid environments, ${ }^{25}$ making the person particularly vulnerable to rise in temperature. In humid environments, moisture can be condensed in body, resulting in a gain of heat, ${ }^{11}$ which might alter the thermographic image captured.

Beyond the control of the variables related to the environmental conditions for the applicability of the TIR, it is also important to track the time to acclimate the individual must first stay in the room. The time of acclimatization is necessary in order to achieve adequate stability in temperature. ${ }^{26}$ Table 2 presents the description of acclimatization time used in the studies. Of the 12 articles selected for review, seven used 15 minutes to acclimate the body of the evaluated. The studies demonstrated good results with acclimatization time of 15 minutes, with a minimum of 10 minutes. ${ }^{26}$ In a study conducted with athletes in soccer players, they remained in the room with air-conditioned environment for 15 minutes and it was concluded that the TIR has good potential for the diagnosis of MI. ${ }^{16}$ According to some authors, ${ }^{27}$ the thermal balance becomes possible through the integration of the mechanisms that alter the heat transfer, regulating the cooling and modifying the production of heat by the body.

Regarding the position that the individual must stay during the acquisition of the thermographic image, Table 2 presents the description of the position used in the studies. Of the 12 articles selected for review, two did not describe the position of the individual during the acquisition of the image, nine of them were measured with the assessed in orthostatic position, and two used different positions, in accordance with the objective of the study in question. Some authors ${ }^{12}$ established that the assessed must stay in the orthostatic position without touching any skin surface. During the use of the TIR, the subjects should be instructed not to palpate the skin and prevent manipulation of the region to be examined, for example, by chairs or parts of the body itself. ${ }^{6}$ In this sense, does not seem to exist a pattern position for the acquisition of thermographic images, but ideal positions in accordance with the segment to be evaluated. The body position during use of the thermographic camera is determined in accordance with the region of interest.1

In addition to the position to capture of thermographic images, few studies cited the clothing of the evaluated. The surface of the body exposed to the environment influences the heat loss. ${ }^{28}$ Some authors ${ }^{10,12}$ Demonstrate that it is important for the evaluated keep naked to assist in thermal stabilization. Clothing can have effects on thermoregulation, by isolating the body of its adjacencies ${ }^{29}$ and influences the processes of heat exchange.

The usefulness of the TIR has been observed frequently in the sporting environment. ${ }^{13}$ Its use can help prevent $\mathrm{MI}$, as an indirect way of measuring the musculoskeletal damage. ${ }^{30}$ The thermal asymmetry in the 
area possibly affected can be compared with the contralateral region of the body, ${ }^{14}$ and this asymmetry can be able to demonstrate physiological and metabolic changes. ${ }^{6,12,14}$ However, some doubts in relation to the control variables for the use of the TIR underline the need for further studies that specify and justify best how to control these variables. Despite the number of articles found in the search, few articles have brought all the control variables analyzed in this review. In addition, the articles selected for this review has not brought the justification of the use of many of the control variables used during the applicability of the TIR. All the variables analyzed, when you do not have thorough control, may preclude the use of the TIR for the funcional evaluation for identification and prevention of muscle injuries.

\section{CONCLUSION}

We can conclude that the TIR is a suitable tool for evaluation and prevention of $\mathrm{Ml}$ in athletes, and that should be taken into consideration some care with the control variables during its use. Seems to be more appropriate to carry out the capture of the thermographic image keeping the room temperature between 18 and $25^{\circ} \mathrm{C}$ fo
15 minutes to acclimate and with the individual in accordance with the segment to be assessed, without contact with another object. It was not possible to establish a consensus regarding the relative humidity of the air is ideal. Also it would be important to have a program - software that after the thermographic assessment, perform a specific measurement of data captured by the thermographic camera and indicate the scores for the levels of inflammation, the inflammatory process and possible injury. In this way the rater bias and level of knowledge of the evaluator could be minimized.

\section{ACKNOWLEDGMENTS}

The authors thank to the Universidade Federal de Minas Gerais (UFMG), the Centro de Estudos em Psicobiologia e Exercício (CEPE), the Fundo de Amparo à Pesquisa de Minas Gerais (FAPEMIG), Coordenação de Aperfeiçoamento de Pessoal à Nível Superior (CAPES) e ao Conselho Nacional de Pesquisa (CNPQ).

All authors declare no potential conflict of interest related to this article

AUTHORS'CONTRIBUTIONS: Each author made significant individual contributions to this manuscript. FV (0000-0002-9051-3103)* theoretical research, data collection, analysis of the results, discussion of the data and writing the manuscript; MTM (0000-0003-3896-2208)* and AS (0000-0001-8155-4723)*: theoretical research, analysis of the results, discussion of the data and writing the manuscript; SAR (0000-0002-3518-5071)*: data collection, discussion of the data and writing the manuscript; CMAC (0000-0001-9761-9448)*: theoretical research analysis of the results and discussion of the data; LSNF (0000-0002-9454-2219)*: analysis of the results, discussion of the data and writing the manuscript; ELR (0000-0001-8796-3501)*: theoretical research, discussion of the data and writing the manuscript. All the authors approved the final version of the manuscript. *ORCID (Open Researcher and Contributor ID).

\section{REFERENCES}

1. Chan O, Buono AD, Best TM, Maffulli N. Acute muscle strain injuries: a proposed new classification system. Knee Surg Sports Traumatol Arthrosc. 2012;20(11):2356-62.

2. Fernandes TL, Pedrinelli A, Hernandez AJ. Lesão muscular: fisiopatologia, diagnóstico, tratamento e apresentação clínica. Rev Bras Ortop. 2011;46(3):247-55.

3. Ekstrand J, Hagglund M, Walden M. Epidemiology of muscle injuries in professional football (soccer). Am J Sports Med. 2011;39(6):1226-32.

4. Hallen A, Ekstrand J. Return to play following muscle injuries in professional footballers. J Sports Sci. 2014;32(13):1229-36.

5. Ekstrand J. Keeping your top players on the pitch: The key to football medicine at a professional level. Br J Sports Med. 2013;47(12):723-4.

6. Mueller-Wohlfahrt HW, Haensel L, Mithoefer K, Ekstrand J, English B, McNally S, et al. Terminology and classification of muscle injuries in sport: the Munich consensus statement. Br J Sports Med. 2013;47(6)342-50.

7. Bandeira F, Neves EB, Moura MA, Nohama P. A termografia no apoio ao diagnóstico de lesão muscular no esporte. Rev Bras Med Esporte. 2014;20(1):59-64.

8. Comin J, Malliaras P, Baquie P, Barbour T, Connell D. Return to competitive play after hamstring injuries involving disruption of the central tendon. Am J Sports Med. 2013;41(1)111-5.

9. Jarvinen TA, Jarvinen TL, Kaariainen M, Kalimo H, Jarvineen M. Muscle injuries: biology and treatment. Am J Sports Med. 2005;33(5)745-64

10. Lima RP, Brioschi ML, Teixeira MJ, Neves EB. Análise termográfica de corpo inteiro: indicações para investigação de dores crônicas e diagnóstico complementar de disfunções secundárias. Pan Am J Med Thermol. 2015;2(2)70-7.

11. Quesada Jl, Palmer RS, Anda RM. Physics principles of the infrared thermography and human thermorregulation. In: Quesada Jl. Application of infrared thermography in sports science. Cham: Springer. 2017;25-48.

12. Brioschi ML, Cherem AJ, Ruiz RC, Sardá Júnior JJ, Silva FM. O uso da termografia infravermelha na avaliação do retorno ao trabalho em programa de reabilitação ampliado (PRA). Acta Fisiatr. 2009;16(2):87-92.

13. Hildebrandt C, Raschner C, Ammer K. An overview of recent application of medical infrared thermography in sports medicine in Austria. Sensors (Basel). 2010;10(5):4700-15.

14.Marins JC, Fernández-Cuevas I, Arnaiz-Lastras J, Fernandes AA, Sillero-Quintana M. Applications of infrared thermography in sports: a review. Rev Int Med Cien Activ Fis Deporte. 2015; 15(60):805-24.
15. Ammer K. Temperature changes after manual examination of the cervical spine. Thermology International. 2002;12(4):147-52.

16. Bandeira F, Moura MA, Souza MA, Nohama PA, Neves EB. Pode a termografia auxiliar no diagnóstico de lesões musculares em atletas de futebol? Rev Bras Med Esporte. 2012;18(4):246-51.

17. Chudecka M, Lubkowska A. Thermal maps of young women and men. Infrared Physics \& Technology. 2015;69:81-7.

18. Merla A, Mattei PA, Donato LD, Romani GL. Thermal imaging of cutaneous temperature modifications in runners during graded exercise. Ann Biomed Eng. 2009:38(1):158-63.

19. Oliveira J, Vardasca R, Pimenta M, Gabriel J, Torres J. Use of infrared thermography for the diagnosis and grading of sprained ankle injuries. Infrared Physics \& Technology. 2016;76:530-41.

20. Salazar-López E, Domínguez E, Ramos VJ, Fuente J, Meins A, lborra O, Gálvez G, Rodríguez-Artacho MA, Gómez-Milán E. The mental and subjective skin: emotion, empathy, feelings and thermography. Conscious Cogn. 2015;34:149-62.

21. Silva YA, Santos BH, Andrade PR, Santos HH, Moreira DG, Sillero-Quintana M, Ferreira JJA. Skin temperature changes after exercise and cold water immersion. Sport Sci Health. 2017;13(1):195-202.

22. Zaproudina N, Ming Z, Hanninen OOP. Plantar infrared thermography measurements and low back pain intensity. J Manipulative Physiol Ther. 2006;29(3):219-23

23. Massari G, Massari I. Damp buildings, old and new. Assoc Preser Technol Int. 1985;17(1):2-30.

24. Grinzato E. Humidity and air temperature measurement by quantitative infrared thermography. QIRT Journal. 2010;7(1):55-72.

25. Johson JM. Exercise in a hot environment: the skin circulation. Scand J Med Sci Sports. 2010(Suppl 3):29-39.

26. Marins JC, Moreira DG, Cano SP, Quintana MS, Soares DD, Fernandes AA, et al. Time required to stabilize thermographic images at rest. Infrared Phys Technol. 2014;65:30-5.

27. Kenny GP, Journeay WS. Human thermoregulation: separating thermal and nonthermal effects on heat loss. Front Biosci (Landmark Ed). 2010;15:259-90.

28. Pham DD, Lee JH, Lee YB, Park ES, Kim KY, Song JY, et al. Novel anthropometry-based calculation of the body heat capacity in the korean population. PLos One. 2015;10(11):e0141498.

29. Romanovksy AA. Skin temperature: its role in thermoregulation. Acta Physiol (Oxf). 2014;210(3):498-507.

30. Fernandes AA, Pimenta EM, Moreira DG, Marins JC, Garcia ES. Application of infrared thermography in the assessment of muscle damage in elite soccer athletes. MOJ Orthop Rheumatol. 2017:8(5):00328. 